\title{
How is Shrimp Aquaculture Transforming Coastal Livelihoods and Lagoons in Estero Real, Nicaragua?: The Need
}

\section{to Integrate Social-Ecological Research and Ecosystem-Based Approaches}

Karina Benessaiah $^{1}$ and Raja Sengupta ${ }^{2}$

${ }^{1}$ School of Geographical Sciences and Urban Planning, Arizona State University, Coor Hall, 5th floor, 975 S. Myrtle Ave.

Tempe, AZ 85287. Email: kbenessa@asu.edu

${ }^{2}$ Department of Geography, McGill University, 805 Sherbrooke West, Montreal, QC H3A 2K6 Canada

\begin{abstract}
Ecosystem-based approaches to aquaculture integrate environmental concerns into planning. Social- ecological systems research can improve this approach by explicitly relating ecological and social dynamics of change at multiple scales. Doing so requires not only addressing direct effects of aquaculture but also considering indirect factors such as changes in livelihood strategies, governance dynamics, and power relations. We selected the community of Puerto Morazán, Nicaragua as a case study to demonstrate how the introduction of small-scale aquaculture radically transformed another key livelihood activity, lagoon shrimp fishing, and the effects that these changes have had on lagoons and the people that depend on them. We find that shrimp aquaculture played a key role in the collapse, in the 1990s, of an existing lagoon common-property management. Shrimp aquaculture-related capital enabled the adoption of a new fishing technique that not only degraded lagoons but also led to their gradual privatization. The existence of social ties between small-scale shrimp farmers and other community members mitigated the impacts of privatization, illustrating the importance of social capital. Since 2008, community members are seeking to communally manage the lagoons once again, in response to degraded environmental conditions and a consolidation of the shrimp industry at the expense of smaller actors. This research shows that shrimp aquaculture intersects with a complex set of drivers, affecting not only how ecosystems are managed but also how they are perceived and valued. Understanding these social-ecological dynamics is essential to implement realistic policies and management of mangrove ecosystems and address the needs of resource-dependent people.
\end{abstract}

Keywords Shrimp aquaculture; Coastal livelihoods; Lagoon fisheries; Common-property management; Ecosystembased management; Social-ecological 


\section{Introduction}

Tropical wetlands such as mangroves provide numerous ecosystem services such as food, erosion control, water purification, sediment trapping, carbon sequestration, nursing, and feeding grounds for many species, as well as spiritual and cultural enrichment (Lacerda 2002; Moberg and Ronnback 2003; Nagelkerken et al. 2008; Walters et al. 2008; Donato et al. 2011). Yet 30-50\% of global mangroves were lost over the past 50 years (Alongi 2002, p. 341; FAO 2007), with shrimp aquaculture accounting for roughly $38 \%$ of this loss, while other types of aquaculture contribute to another $14 \%$ (Polidoro et al. 2010, p. 2). Given the importance of mangrove-related ecosystem services, combined with staggering mangrove losses in recent decades, more sustainable management approaches are needed.

Assessing shrimp aquaculture trade-offs is no easy task. Indeed, On the one hand, shrimp aquaculture provides an alternative to rapidly overexploited fisheries, a potential source of food and income for the rural poor and much needed capital for developing nations (Tidwell and Allan 2001; FAO 2009). On the other hand, shrimp aquaculture directly impacts mangroves - when ponds are established in wetland areas - and indirectly through changes in hydrology, increased sedimentation and water contamination (Martinez-Alier 2001; Paez-Osuna 2001a, b; Valiela et al. 2001; Lugo 2002; Walters et al. 2008). Also, the rapid growth of high-value aquaculture products, such as shrimp, often generates social conflict between aquaculture developers and other coastal users over the privatization and degradation of what was often a commons (Stonich 1989, 1995; Dewalt et al. 1996; Stanley 1996, 1998; Stonich et al. 1997; Stonich and Bailey 2000; Martinez-Alier 2001; Stonich and Vandergeest 2001; Gowing et al. 2006; Horton 2007; King 2010; Nayak and Berkes 2010). Vulnerable coastal users can be particularly impacted from this privatization (Kent 1997; Primavera 1997; Adger 2000; Adger and Luttrell 2000; Armitage 2002; Luttrell 2006; Bergquist 2007; Nayak and Berkes 2011). Indeed, aquaculture often transforms the various management regimes that coexist de facto in estuarine coastal lowlands, and that range from private to common-property or open-access conditions ${ }^{1}$. The management regimes observed at a local level depend greatly on their socioeconomic context, the nature of these resources, and the existence of exogenous factors influencing the first two factors (such as laws and international prices) (Ostrom 1990; Ostrom et al. 1999). When a resource becomes hard to exclude and/or its substractability increases due to changes in population, extraction technology, or in the resource (value or quantity) itself, common-property management schemes tend to collapse or transform (Kapetsky 1981; Ostrom et al. 1999; Seixas 2000; Kalikoski et al. 2002; Seixas and Troutt 2003; Seixas and Berkes 2003; Berkes and Seixas 2005; Kurien 2005; Singh 2005). Thus, shrimp aquaculture can increase or decrease the resilience of coastal communities depending on how the aquaculture-livelihoods-wetlands relationship is configured (Adger 2000; Stevenson et al. 2009).

In response to these potentially negative social and environmental impacts, aquaculture researchers advocate for

\footnotetext{
${ }^{1}$ Here private property refers to areas where an individual or a corporation has exclusive rights, determining access and levels of exploitation, while common-pool resources refers to areas where control of access is difficult (i.e., exclusion is costly) and resource are substractable (i.e., use reduces resource availability). Open access refers to areas where "access is free and open to all", similar to the example given by Hardin in his famous article on the 'tragedy of the commons'.
} 
an "ecosystem approach" to aquaculture which ideally promotes development, equity, and resilience of interlinked social and ecological systems (Frankic and Hershner 2003; Soto et al. 2008). According to the Food and Agricultural Organization (FAO) "an ecosystem approach to aquaculture (EAA) strives to balance different societal objectives, by taking account of the knowledge, and uncertainties of biotic, abiotic and human components of ecosystems including their interactions, flows and processes, and applying and integrated approach within ecologically and operationally meaningful boundaries" (FAO 2006). EAA thus adopts a system-based approach to aquaculture that looks at multiple scales, from assessing ecosystem functioning and services at the aquaculture site to a complete ecosystem level assessment. One challenge is that many ecologists and managers tend to define ecosystems in a localized sense, a "distinct and coherent ecological community of organisms and the physical environment with which they interact" (Slocombe 1993, p. 612), rather than adopting a broader understanding of ecosystems as self-organizing units comprised of interacting ecological and social components operating at different scales. Thus, while recognizing the need to better relate social dynamics to ecosystems, ecosystem-based approaches still rely on a narrow understanding of social dynamics (Berkes 2012).

We argue that adopting a social-ecological systems (SES) approach—also called coupled human-environment approach in fields such as sustainability and vulnerability - explicitly conceptualizes coastal issues as an integrated system of people and environments, interconnected across scales, from the local to the global (Berkes et al. 2003; Turner et al. 2003; Nayak and Berkes 2012). SES aims to iteratively relate ecological dynamics of change and resilience (i.e., the ability of an ecosystem to retain its functions and structure, to self-organize, when faced with change) to social dynamics such as livelihood strategies, governance dynamics, knowledge systems, and power relations (Berkes et al. 2000, 2003; Peterson 2000; Folke 2006).

Doing so requires addressing not only the ecological and economic dimensions of aquaculture growth, but also the emergent social feedbacks and pathways that affect both marine/coastal ecosystems and coastal livelihoods by changing customary land and sea tenure (Seixas and Troutt 2003; Kurien 2005; Berkes 2006; Nayak and Berkes 2011). In short, aquaculture research should look beyond proximate drivers of change, i.e., direct impacts of aquaculture such as the conversion of mangroves to aquaculture ponds, and examine more fully the underlying drivers of change; notably how aquaculture affects other livelihood activities in the system, the institutions that regulate those activities, and the coastal system itself.

To illustrate how an SES perspective can enhance aquaculture management, we took on a Latin American case study using the example of the community of Puerto Morazán in the Estero Real (Nicaragua), which has direct implications for addressing the global mangrove crisis outlined above as $40 \%$ of mangroves species in Central America are at risk of extinction (Polidoro et al. 2010). Specifically, we illustrate how the emergence of small-scale shrimp aquaculture impacts another key activity, lagoon fisheries, by changing its management and beneficiaries; and discuss the implications of such changes for the sustainability of this coastal social-ecological ecosystem. While focusing mainly on the direct and indirect 
role played by shrimp aquaculture, the study also examines the importance of other drivers, exogenous to the local economic systems, such as climate change and global demand for shrimp.

\section{Study Area}

Shrimp aquaculture has experienced considerable growth, averaging $8.8 \%$ annually since the 1980 s due to an increased demand for seafood (FAO 2007). Asia, with its long tradition in aquaculture, accounts for $89 \%$ of the world's aquaculture production, followed by Latin America with $4.30 \%$ (FAO 2012a, b, p. 27). Shrimp remains the most valuable global fishery commodity representing $15 \%$ of the total value of traded fishery products in 2010 (FAO 2012b, p. 77).

Initial efforts to develop shrimp aquaculture in Nicaragua occurred in the community of Puerto Morazán, Estero Real (study site shown in Fig 1) in the early 1980s with the support of the socialist Sandinista government (CIDEA 2006). These efforts intensified in the 1990s, a decade with favorable conditions for shrimp farming due to high international prices, low input costs, and good environmental conditions in the Estero Real (Coze Saborío 2006). Currently, shrimp aquaculture is concentrated in two estuaries located on the Pacific, the Estero Real, and Padre Ramos, providing $2.3 \%$ of Nicaragua's total export in 2012 for an aggregated value of 61.2 million dollars, compared to $3.7 \%$ of total exports and 38.3 million annually at the time of this study in 2006 (MIFIC 2007, p. 16; MIFIC 2013, p. 31). At that time, there were 13,151 ha of shrimp ponds in the Estero Real, with shrimp cooperatives operated by members of nearby communities representing about 5,000 ha and the rest belonging to large-scale corporate shrimp farms (Núñez-Ferrera 2003; Coze Sabor1'o 2006; Benessaiah 2008). Since 1996, the shrimp industry in Nicaragua has been undergoing a consolidation phase, whereby large-scale industrial shrimp farms have been buying out or leasing small-scale shrimp farms; a process potentially detrimental to sustainable rural community development (Núñez-Ferrera 2003; Donnelly 2007; Wittenstein 2007; Benessaiah 2008). In Puerto Morazán, the number of cooperatives decreased from 154 to 54 from 1994 to 2006 , mostly due to the combined catastrophic impacts of hurricane Mitch (1998) and White-Spot disease (1999/2000) which greatly indebted the small-scale shrimp industry (Benessaiah 2008). It is in this context of increasing consolidation of the shrimp industry that we assessed changes in another key livelihood activity: lagoon shrimp fishing.

It is not a coincidence that shrimp aquaculture started in the Estero Real as it is part of the Gulf of Fonseca, an extremely fertile 70,000 ha of interdependent patches of mangroves, salt flats, marshes, and lagoons shared by Honduras, El Salvador and Nicaragua (Ramsar 2000). Rainfall in the Estero Real averages 1,600 mm/year with about $95 \%$ occurring during the wet season from May/June to October/November (MARENA 2006). Two main seasons (wet and dry), thus regulate livelihood activities: lagoon fishing and small-scale shrimp farming occurring only during the wet season. Indeed, seasonal lagoons then expand as sea waters meet with surface water from the highlands (Núñez-Ferrera 2003). These lagoons are important biodiversity habitats, hosting aquatic larvae during part of their reproductive cycle, and providing refuge to migratory birds (Núñez-Ferrera 2003; Vásquez et al. 2005). This ecological importance is reflected in the 
recognition of the Estero Real as a protected area as early as 1983, and as a Ramsar site in 2001. Due to their high biological diversity, these lagoons are also key fishing sites for several surrounding communities, including Puerto Morazán.

Figure 1. Lagoons and shrimp ponds in the Estero Real, Nicaragua (2006)

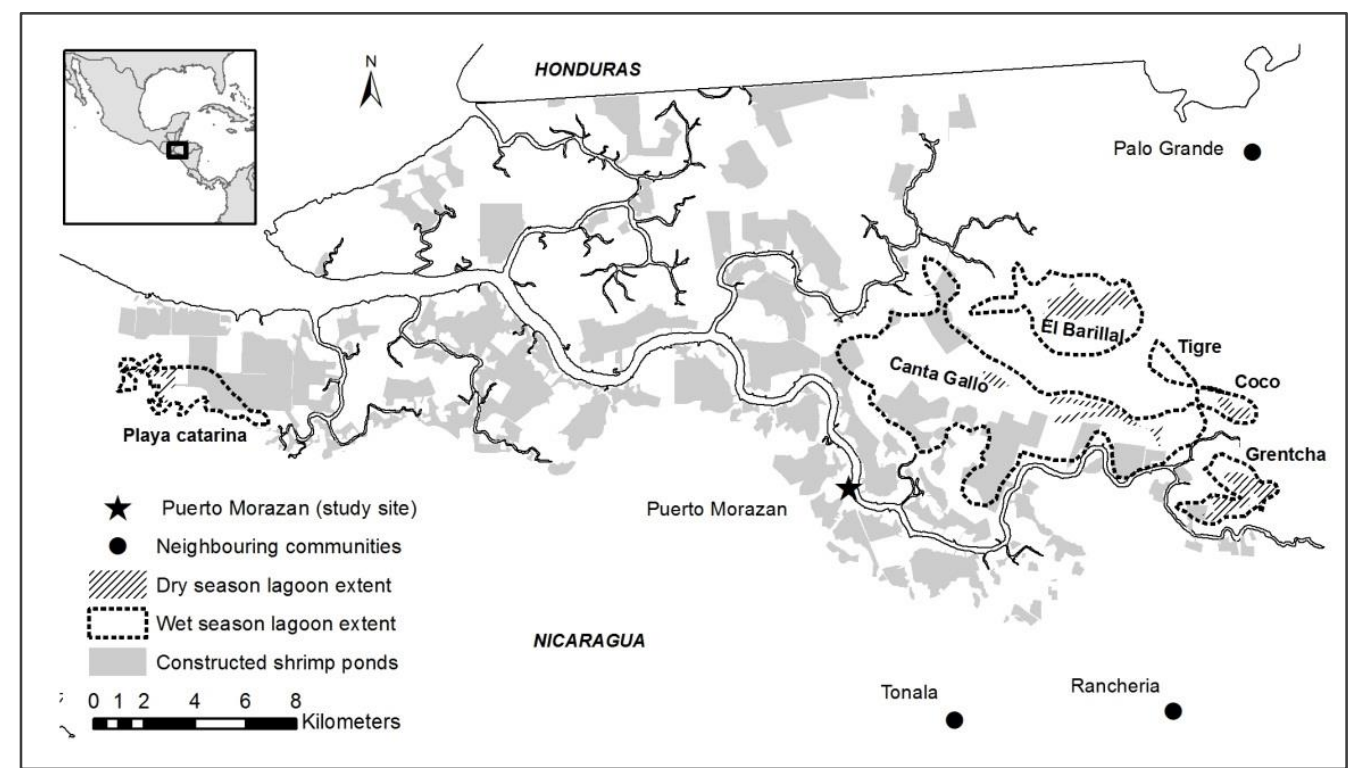

Lagoon size varies during dry and wet seasons (represented graphically by hashed vs. dashed areas respectively). Canta Gallo- the largest lagoon and the one closest to the community of Puerto Morazán- had a dry season extent of 195 ha vs. 4500 ha in the wet season in 2005-2006 (estimated using satellite imagery and GPS ground validation). Grey areas represent constructed shrimp ponds. Canta Gallo has $34 \%$ of its surface occupied by shrimp ponds, $13 \%$ by industrial ponds and $21 \%$ by shrimp cooperatives.

\section{Methods}

The community of Puerto Morazán pioneered shrimp farming in Nicaragua and remains today dependent on estuary extraction and shrimp aquaculture for its livelihood. It thus constituted an ideal case study to analyze the dynamics introduced by shrimp farming in a coastal community, and understand how these impact another key resource: lagoon fisheries. Additionally CIDEA, a partner institution who provided logistic support for this research, has a base in that community since 1990. The lead author lived in Puerto Morazán from January to May 2006, in September to October of 2006, with a follow-up visit in July 2008, thus getting closely acquainted with the community and its activities during both the dry/wet seasons.

We adopted the sustainable livelihoods framework for the household surveys to cover all aspects of coastal livelihoods, including human, physical, natural, social, and financial capitals for the year 2005 (Ellis 1998; Scoones 1998; Allison and Ellis 2001). Surveys were conducted in Spanish, in 2006 ( $n=75,25 \%$ of the community of Puerto Morazán) with randomly selected households stratified between shrimp farming and non-shrimp farming households. The sampling frame was determined by mapping all the households in the community $(n=297)$ and identifying their occupants and their livelihood strategies with the help of two local informants. The survey had both structured and semi-structured sections. The structured section consisted of a predetermined and standardized set of questions aimed at generating quantitative data 
(i.e., demographics, livelihood activities, history of shrimp farming involvement, incomes for each activity, and assets), while the semi-structured section allowed interviewees to express them-selves freely about their livelihood activities, the history of the community and of individual households, as well as environmental changes observed in the region (Hay 2005, p. 81). Eight additional households were interviewed based on their in-depth knowledge of the dynamics of environmental change in the area. Participant observations and informal interviews complemented the overall analysis. In 2008, a community-based focus-group was also held to present results from the previous survey and discuss subsequent social-ecological changes.

Descriptive statistics and logistic regressions using Stata 12 were performed on the quantitative data $(\mathrm{n}=75)$ collected in 2006, while the qualitative data (82 interviews in 2006 and 15 interviews in 2008) were analyzed after being coded thematically. In the logistic regressions, all likelihood ratio Chi squares had a p value 10.05 , meaning that the models fit significantly better than a null model. Pseudo $\mathrm{R}^{2}$ in logistic regression does not provide the same meaning of variance as in OLS regression, and should, therefore, be interpreted cautiously (Menard 2000; Peng et al. 2002). To assess model fit, we thus computed other $\mathrm{R}^{2}$ indices - Cox and Snell (1989) and Nagelkerke (1991), as well as other measures of goodness of fit including: (a) area under ROC curve (AUC), which is a measure of the model's discrimination ability ;(b) percent of correct classification, based on a cross-tabulation of observed versus predicted outcomes; and (c) the Hosmer-Lemshow test, which if insignificant ( $p>0.05$ ) suggests the model fits the data satisfactorily (Hosmer and Lemeshow 2000).

Household members were also asked to identify on a map where lagoons, fishing spots, and associated fishing camps are located. Given that not all households felt comfortable with maps, direct visits were also organized to fishing camps, shrimp farms, lagoons, and other estuarine areas. We assessed lagoons' extent and location based on participatory GIS mapping, a classification using a SPOT image for 2006, and in-field GPS measurements during the dry and wet season in 2006 since lagoons were not officially mapped (Fig. 1).

\section{Results}

\section{Fishery-Based Livelihoods-The Importance of Lagoon Fisheries}

In 2005-2006, Puerto Morazán residents relied mostly on fisheries and small-scale shrimp aquaculture for their livelihoods, with the following distributions explaining the sources of the community's yearly income (in USD): $42 \%$ from capture fisheries of shrimp, fish, and shellfish, $11 \%$ from shrimp farming, and 9 and $8 \%$, respectively, from wage employment from shrimp farms and seafood trading. Shrimp in particular is a high-value commodity obtained mostly during the wet season (May/June to Oct/Nov) as lagoons and shrimp ponds get filled. Shrimp occupies such an important role in the community that one interviewee jokingly said: "we are all into shrimp" ${ }^{2}$. The decline of lagoon shrimp fisheries was identified as a main concern by $87 \%$ of the interviewees given that these provide $15 \%$ of the community's yearly income, second only to services

\footnotetext{
${ }^{2}$ All quotes from the interviews are translated from Spanish.
} 
(25\% income share).

The Estero Real has eight main lagoons, which vary greatly in extent between wet and dry seasons (Fig. 1). Residents of the community of Puerto Morazán mainly used the lagoons of Canta Gallo ${ }^{3}$ - the largest lagoon complex and the one closest to the community with an area ranging from 195 to 4,500 ha from dry to wet season. Other lagoons were used in the past, e.g., Horcones, Barillal, Playa Catarina, Grentcha, Tigre, and Coco, but conflicts with neighboring communities and environmental changes reduced the number of accessible lagoons. Additionally, in 2006, $13 \%$ of Canta Gallo lagoons were occupied by industrial shrimp ponds and another $21 \%$ by small-scale cooperatives.

Table 1 provides descriptive statistics differentiating among households that did not utilize the lagoons $(\mathrm{n}=23)$ to those that accessed the lagoons directly $(\mathrm{n}=25)$, using their own boats and fishing gear, or as fishing labor called moso $(\mathrm{n}=27)$ in exchange for a share of the shrimp catch (usually $1 / 3$ for the worker and 2/3 for the owner of the fishing equipment). Figure 2 presents mean annual income per activity (2005).

Among the households that did not utilize the lagoons, services provided $44 \%$ of income, followed by shrimp farming and seafood trade that provided 16 and $11 \%$, respectively. However, services and seafood trade are dominated by a few households that skew the measurement of aggregated incomes. One household in particular gets $1 / 4$ of services and another $1 / 4$ of the seafood trade income share. This group presents higher levels of overall income inequality (0.52 gini coefficient). We thus observed households with low incomes and assets coupled with a few rich households that did not engage in lagoon fisheries, but rather in seafood trading and services. Notwithstanding the richest household in the community, households that did not utilize the lagoons have incomes and assets similar to those who were employed as mosos, both of whom are among the poorest in the community (Fig. 3).

For those that utilized the lagoons directly, lagoon fisheries provided the largest share of their yearly income (23 \%), followed by services, other fisheries, and shrimp farming (12\%); while those that entered as mosos also derived most of their yearly income from lagoon fisheries $(21 \%)$, followed by services, fishing, and shrimp wage labor (15-18 \% income share range). Gini coefficients are lower for those two groups, 0.24 and 0.23 , respectively, meaning that these groups have a more homogenous income distribution. Lagoon shrimp fishery earnings were considerably lower for households entering as mosos, averaging US\$616 (vs. US\$1283 for those with direct access).

Those entering lagoons as mosos tend to be younger and slightly less educated, with a quarter being newcomers to the community (i.e., having arrived within the last 10 years). Further, $63 \%$ of them rely on their social network s to access boats and fishing equipment. Only a quarter were involved in shrimp farming in 2005, $15 \%$ used to be shrimp farmers in the past, and a striking $59 \%$ were never involved in shrimp farming. In contrast, almost half of households that utilized the lagoons directly were involved in shrimp farming in 2005 , while more than a third used to be in shrimp farming previously, and only a

\footnotetext{
${ }^{3}$ Some residents differentiate between Canta Gallo and Canta Gallito, a smaller lagoon subsumed within Canta Gallo. We include both when we refer to the Canta Gallo lagoons.
} 
quarter were never involved in shrimp farming.

Table 1. Descriptive statistics, Puerto Morazán, Nicaragua (2005) by group

\begin{tabular}{|c|c|c|c|c|c|}
\hline \multicolumn{2}{|c|}{$\begin{array}{l}\text { A: All households / B: Did not enter the lagoons/ C: Entered the } \\
\text { lagoons with own fishing equipment/ D: Entered the lagoons as } \\
\text { fishing labor (mosos) }\end{array}$} & (N=23) & ( $\mathbf{N}=25)$ & $(\mathrm{N}=27)$ & KW \\
\hline \multirow{2}{*}{ 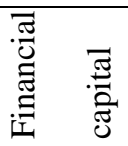 } & Total mean income (USD/year) & 4291 & 5228 & 3245 & $* * *$ \\
\hline & \# income sources (diversification proxy) & 4.70 & 6 & 6.48 & $* * *$ \\
\hline \multirow{6}{*}{ 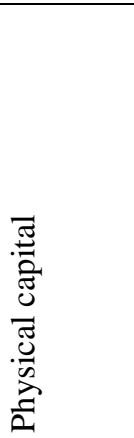 } & Assets total (USD) & 1748 & 5375 & 663 & $* * *$ \\
\hline & Marine transport (i.e. boats and motors) (USD) & 212 & 2716 & 23 & $* * *$ \\
\hline & Fishing gear (USD) & 109 & 1758 & 191 & $* * *$ \\
\hline & Forest extraction assets (USD) & 29 & 18 & 4 & $* * *$ \\
\hline & Land transport (i.e. car, motorcycle) (USD) & 259 & 113 & 55 & \\
\hline & Freezer (USD) & 246 & 169 & 78 & \\
\hline \multirow{4}{*}{ 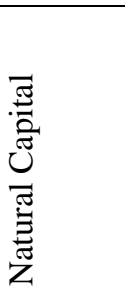 } & Shrimp concession $(\mathrm{Ha})$ & 6.35 & 6.18 & 3.15 & $*$ \\
\hline & Shrimp ponds (Ha) & 4.94 & 4.81 & 2.29 & $*$ \\
\hline & Agricultural land (Ha) & 1.10 & 0.25 & 0.11 & \\
\hline & Farm animals (USD) & 320 & 30 & 15 & $*$ \\
\hline \multirow{5}{*}{ 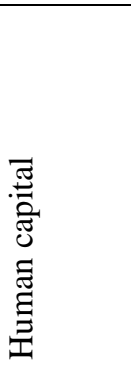 } & Number of household members & 5.13 & 5.64 & 5.44 & \\
\hline & Male active members & 1.22 & 1.6 & 1.44 & $*$ \\
\hline & Female active members & 1.48 & 1.68 & 1.56 & \\
\hline & Age household head & 45 & 45.32 & 37.63 & $* *$ \\
\hline & Household head education (years) & 5.13 & 3.92 & 3.41 & \\
\hline \multirow{5}{*}{ 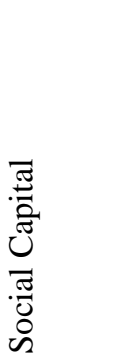 } & Accessed boat and fishing equipment through & $17 \%$ & $0 \%$ & $63 \%$ & $* * *$ \\
\hline & social network (friends and family) (\%) & & & & \\
\hline & Housing structure (1-3.5)- low to high quality & 2.16 & 2.42 & 1.96 & \\
\hline & Time in community (years) & 33 & 32.64 & 25.74 & \\
\hline & Newcomers (\%)- (came within 10 years) & $13 \%$ & $0 \%$ & $26 \%$ & $* *$ \\
\hline \multirow{4}{*}{ 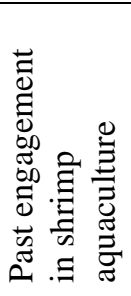 } & Has a shrimp pond in $2005(\%)$ & $61 \%$ & $48 \%$ & $26 \%$ & $* *$ \\
\hline & Never had a shrimp pond (\%) & $35 \%$ & $24 \%$ & $59 \%$ & $* *$ \\
\hline & Used to be a shrimp farmer but no longer (\%) & $4 \%$ & $32 \%$ & $15 \%$ & $* *$ \\
\hline & Parents are shrimp farmers $(\%)$ & $35 \%$ & $20 \%$ & $15 \%$ & \\
\hline
\end{tabular}


Figure 2. Mean annual income per activity (2005) differentiating households that did not enter the lagoons, to those that entered the lagoons directly (i.e. using their own fishing equipment) or as mosos (i.e. fishing labor)

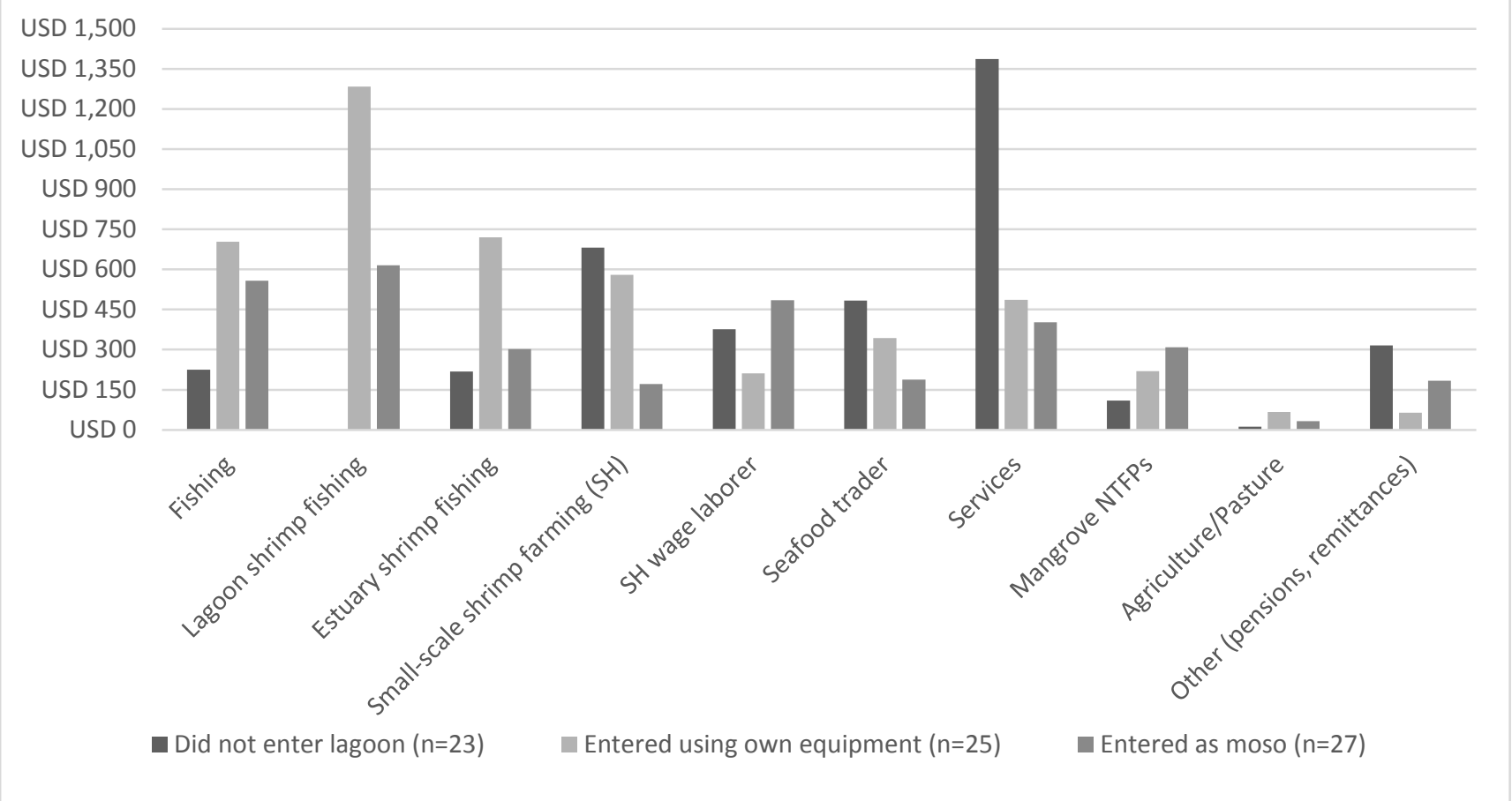

Fishing refers to the capture fishery of species such snappers, snooks, weakfish using gillnets and hooklines. Lagoon shrimp fishing refers to the capture of shrimp in seasonal lagoons during the wet season (Penaeus vannamei and P. Occidentalis) using bagnets in combination with a plastic wall (plastico) and sometimes castnets. Estuary shrimp fishing started in 2000 for the capture of a smaller dry-season shrimp (Trachypenaeus byrdi) using bagnets. Shrimp farming here refers to the pond rearing of shrimp (P. Vannamei) by Puerto Morazán community members. SH wage labor refers to employment in shrimp farms. Seafood trader are intermediaries, usually women, purchasing seafood products directly from fishers and small-scale farmers for sale in national/regional markets. Services include all off-farm activities. Mangrove non-timber forest products (NTFPs) refer here to shellfish and firewood collection and hunting. Agriculture/Pasture refers to farming and rearing of small livestock and cattle. Finally other here refers to pensions, remittances, aid, interests on loans.

Figure 3. Frequencies of total incomes and total assets (2005) by group (no entry, direct entry, entry as moso)

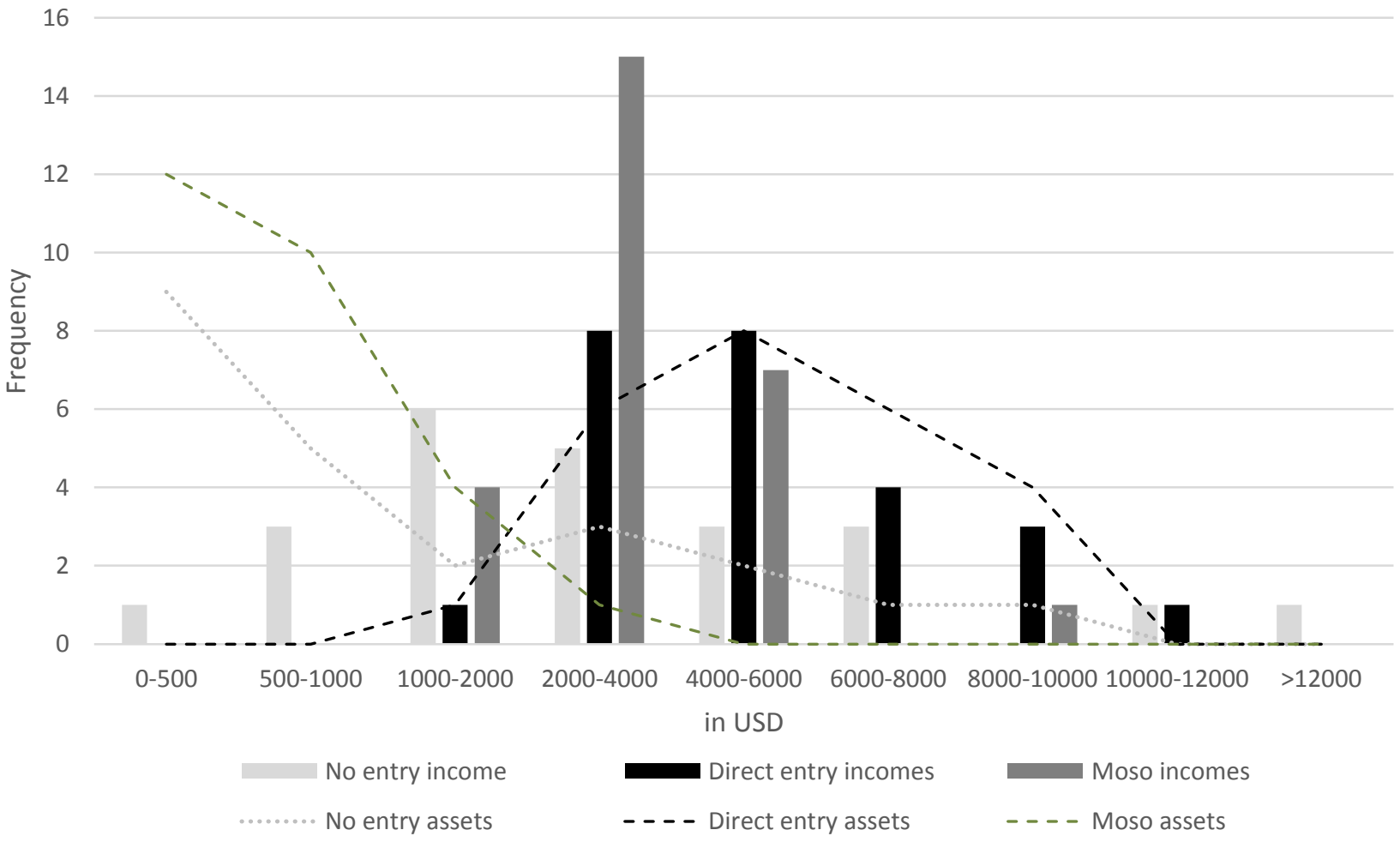




\section{What Factors Best Explains Lagoon Entry?}

Table 2 presents logistic regression models explaining direct lagoon entry (model 1), i.e., using own boat/motor, and lagoon entry as moso (model 2), i.e., as fishing labor, based on: the age of the household head, ratio of male active members (15-65 years old), being an active shrimp farmer (0/1), having been a shrimp farmer in the past (0/1), fishing assets value (boat, motor and nets), fishing equipment access through friends and family (0/1), and number of income sources (proxy for livelihood diversification).

For those utilizing the lagoon directly (model 1), having fishing assets is the most significant factor explaining lagoon entry. Each additional 100USD investment in fishing assets makes it about $30 \%$ more likely that the household will be a direct user of the lagoon (odd ratio of 1.30). On the contrary, for those accessing the lagoon as mosos, having your own fishing gear (but no boat/motor) makes it slightly less likely that you will enter the lagoons. In this group, households that have access to fishing assets (including boat/motor) through friends or family are 11 times more likely to engage in lagoon fishing. Further, lagoon fisheries were part of a diverse livelihood diversification strategy, for this group, given that the likelihood of engaging in lagoon fishing doubles with each additional income source.

Both these models show that lagoon utilization is primarily facilitated through ownership or access to boats and fishing gear. Clearly, households possessing or accessing boats and fishing gear can visit lagoon areas and are thus more likely to engage in lagoon fishing. The reliance on equipment loaned from family members and friends highlights the importance of social network for access to lagoon fisheries.Households that have high social capital have the opportunity to engage in lagoon fishing, thus enabling often poorer households of an extended network to benefit from lagoon earnings. This allows benefits to trickle down to less fortunate households in the family's extended social network, and in return it allows (wealthier) households reliable access to labor. However, it also restricts households that are not well connected, or newcomers, from receiving the benefits of utilizing the lagoons, thus highlighting both the positive and negative aspects of social capital (Crona and Bodin 2006; Turner 2007).

Given the importance of productive assets, we also looked at factors explaining ownership of marine transport (model 3) and ownership of plastico (model 4), i.e., sheets of heavy duty plastic membranes coupled with a bag-net used by lagoon fishers to dam part of the lagoon leaving a single exit to catch shrimp (Fig. 4). Independent variables for both models included: age of household head, percentage of male active members, being a small-scale shrimp farmer in 2005-2006, having been a small-scale shrimp farmer previously, and number of income sources (proxy for diversification). Households that were into shrimp farming previously are almost six times more likely to own their own marine transport and 23 times more likely to own plastico. Indeed, shrimp farming brought considerable amounts of financial returns to small-scale shrimp farmers in the 1990s, a capital that many reinvested into fishing productive assets. Being a shrimp farmer in 2005-2006 and having access to additional male labor are also factors that favorably enhanced the likelihood of owning plastico, first because shrimp farmers tend to be richer than non-shrimp farming households and are thus able to purchase the relatively costly plastico, and second 
because many lagoon fishers are also shrimp farmers, sharing labor between lagoon fisheries and shrimp farming.

Table 2. Logistic regression models explaining lagoon entrance and fishing asset ownership in Puerto Morazán (2005)

\begin{tabular}{|c|c|c|c|c|}
\hline & Model 1 & Model 2 & Model 3 & Model 4 \\
\hline & Direct Access & Access as 'moso' & Marine Transport & 'Plastico' \\
\hline & & & ownership & ownership \\
\hline Age household head (years) & $1.06(0.94)$ & $1.004(0.14)$ & $1.04(1.53)$ & $0.95(-1.58)$ \\
\hline Household' male active members $(\%)$ & $1.00(0.02)$ & $1.05(1.35)$ & $1.02(0.97)$ & $1.09(2.83) * * *$ \\
\hline Small-scale farmer (dummy) & $0.21(-0.61)$ & $0.20(-1.62)$ & $1.94(1.08)$ & $11.86(2.51)^{* *}$ \\
\hline $\begin{array}{l}\text { Used to be a small-scale } \\
\text { shrimp farmer (dummy) }\end{array}$ & $31.50(1.42)$ & $1.06(0.05)$ & $5.74(2.26)^{* *}$ & $22.62(2.84)^{* * *}$ \\
\hline Fishing assets (in hundreds of USD) & $1.30(2.83) * * *$ & $0.87(-2.32)^{* *}$ & NA & NA \\
\hline $\begin{array}{l}\text { Access to fishing assets } \\
\text { through social network (dummy) }\end{array}$ & NA & $10.77(2.69) * * *$ & NA & NA \\
\hline $\begin{array}{l}\text { Proxy for diversification extent } \\
\text { (number of income sources) }\end{array}$ & $0.93(-1.51)$ & $2.10(2.82)^{* * * *}$ & $1.28(1.46)$ & $0.69(-1.71)^{*}$ \\
\hline Constant & $0.0003(-1.51)$ & $0.003(-2.23) * *$ & $0.01(-2.71) * *$ & $0.21(-0.96)$ \\
\hline No. of observations & 75 & 75 & 75 & 75 \\
\hline LR chi2 & 79.14 & 54.59 & 13.72 & 19.91 \\
\hline Prob $>$ chi 2 & 0.000 & 0.000 & 0.0175 & 0.0013 \\
\hline Pseudo R2 & 0.8289 & 0.5570 & 0.1349 & 0.2409 \\
\hline Log-likelihood & -8.17 & -21.71 & -43.99 & -31.37 \\
\hline \multicolumn{5}{|l|}{ Other measures for model fit } \\
\hline Nagelkerke's R-Square & 0.91 & 0.71 & 0.23 & 0.35 \\
\hline Cox-Snell R-Square & 0.65 & 0.517 & 0.167 & 0.23 \\
\hline AUC & 0.99 & 0.94 & 0.72 & 0.82 \\
\hline Correctly classified & $94.67 \%$ & $89.33 \%$ & $65.33 \%$ & $77.33 \%$ \\
\hline Hosmer-Lemeshow goodness of fit & rejected & rejected & rejected & rejected \\
\hline
\end{tabular}

\section{The Lagoons: A Transformed Social-Ecological System}

The logistic models show that lagoon utilization in 2005 was primarily determined by ownership of fishing assets, or the borrowing of such assets through one's extended social network. Ownership of fishing assets (boats, motors, and fishing gear) was enabled by early involvement in shrimp farming that brought considerable financial capital into the community, especially 
in the 1990s when small-scale shrimp aquaculture was flourishing.

Yet, $87 \%$ of the interviewees felt that the lagoons were in decline, and among other factors, the reliance on plastico as a fishing technique was to blame for not only a perceived biophysical decline of the lagoons but also for restricting access to the lagoons to those that have the means to invest extensively in this particular fishing technique. One interviewee stated: "He who has the most plastico and the best spot in the lagoon earns the most. Before we were taking turns. With plastico, those turns ended." By turns, this interviewee was referring to an organized common-property regime which earlier regulated access and use of the lagoons. Several households commented on what Nayak and Berkes (2011) call in the context of India "decommonization," i.e., the loss of resources previously managed as common-pool resources. In Puerto Morazán, the shift from common-property management to mixed property regimes where some lagoon areas are open-access while others are privatized occurred over time; driven to a great extent by transformations related to the introduction of shrimp aquaculture in the region, in a pattern similar to what occurred in Indian and Vietnamese lagoons (Nayak and Berkes 2011; Huong and Berkes 2011). This is a change which is acutely felt by many residents. One interviewee thus stated: "There is a struggle to recover the lagoons." In the following sections, we discuss the social- ecological factors which initiated the process of decommonization, and how those relate to shrimp aquaculture.

The reasons for establishing a common-property regime for lagoon fisheries were not extensively commented upon. However, several factors that were discussed with interviewees can explain its establishment, congruent with findings from the commons literature (Ostrom 1990; Agrawal 2002), including favorable resource conditions, low population densities which facilitate establishing clear exclusion rules, strong fishermen institutions, sustainable fishing practices, minimal government intervention, and a strong sense of connection (Nayak and Berkes 2011, p. 134). These factors were present in Puerto Morazán prior to the arrival of shrimp aquaculture. Further, in the 1970s, Salvadorian traders created a regional market for estuarine resources including shrimp captured in lagoons, providing credit and equipment and buying at prices superior to those on the national market. Thus, while shrimp had not yet become "pink gold", incentives were present to establish rules for the use of a valuable resource. In the 1980s, the political climate during the Sandinista revolution encouraged the creation of cooperatives and fishing associations, contributing to building stronger fishermen's associations. By the end of this period, eight seasonal lagoons were communally managed by the community of Puerto Morazán. A village committee appointed shifts to each resource user (i.e., limiting access to a specific date in a specific lagoon with a fixed fishing gear) thus managing shrimp fishing spatially, temporally, and technologically. Initially, only cast nets were allowed but eventually bag-nets were allowed. Each fisherman made his own sale arrangements, usually selling to local and Salvadorian traders who sold the captured shrimp as well as other fish in national and/or regional markets. Figure 5 graphically depicts the social- ecological conditions prior and following the introduction of aquaculture in the region.

There are multiple reasons why this common-pool resource regime collapsed, which relate to social-ecological changes linked to the introduction of a high-value activity such as shrimp farming in the region. Interviewed households mentioned 
organizational issues such as increasingly high costs of enforcement of previously agreed upon cooperation rules (i.e., high incidence of free riding), corruption (i.e., rent seeking amongst powerful family network s), as well as changes in lagoon areas access, technology, and population demographics as factors that changed the "rules of the game" (see Table 3 for a synthesis of lagoon fisheries management changes in Puerto Morazán).

Table 3. Lagoon fisheries management changes in Puerto Morazán, Nicaragua.

\begin{tabular}{|c|c|c|c|}
\hline Factors & 1970-1980s & Late 1990s-Mid 2000s & End of 2000s \\
\hline $\begin{array}{l}\text { Local } \\
\text { governance }\end{array}$ & $\begin{array}{l}\text { Common-property lagoon } \\
\text { management }\end{array}$ & $\begin{array}{l}\text { Unorganized- hybrid open- } \\
\text { access and privatized }\end{array}$ & $\begin{array}{l}\text { Hydrid system: efforts towards common- } \\
\text { property lagoon management }\end{array}$ \\
\hline $\begin{array}{l}\text { State } \\
\text { involvement }\end{array}$ & Low & Low & Higher \\
\hline Population & Low & High & High \\
\hline $\begin{array}{l}\text { Extractive } \\
\text { technology }\end{array}$ & Labor-intensive ('ataraya’) & $\begin{array}{l}\text { Capital-intensive : fixed } \\
\text { structures ('plastico') }\end{array}$ & $\begin{array}{l}\text { Capital-intensive: bagnets but not fixed } \\
\text { structures }\end{array}$ \\
\hline \multirow[t]{2}{*}{$\begin{array}{l}\text { Biophysical } \\
\text { conditions }\end{array}$} & $\begin{array}{l}\text { Longer lagoon season } \\
\text { (June-Dec) }\end{array}$ & $\begin{array}{l}\text { Shorter lagoon season (July- } \\
\text { Oct/Nov) }\end{array}$ & $\begin{array}{l}\text { Shorter lagoon season } \\
\text { (July-Oct/Nov) }\end{array}$ \\
\hline & Deeper lagoons & $\begin{array}{l}\text { Shallower lagoons } \\
\text { "2-3 m difference between } \\
1976 \text { and 2003" } \\
\text { (CIDEA 2006) }\end{array}$ & Shallower lagoons \\
\hline $\begin{array}{l}\text { Number of } \\
\text { lagoons used }\end{array}$ & Eight & Two & Two \\
\hline $\begin{array}{l}\text { Shrimp } \\
\text { aquaculture }\end{array}$ & None or few ponds & $\begin{array}{l}\text { Significant pond } \\
\text { encroachment }\end{array}$ & $\begin{array}{l}\text { Pond encroachment but considerable pond } \\
\text { abandonment by small-scale farms }\end{array}$ \\
\hline
\end{tabular}

\subsection{Demographic Changes}

Shrimp farming reconnected Puerto Morazán with national and international markets. It brought attention to an area considered marginal by the state from 1960 to 1980 . Credit for shrimp development was first given by the Sandinista government to cooperatives starting as early as the late 1970s, and then by subsequent governments to industrial shrimp farming initiatives (Coze Saborío 2006). The shrimp boom, which the ending of the war made possible, contributed to a population change as many households that fled the war returned. The shrimp boom also attracted new settlers to Puerto Morazán.

This local population change affected lagoon fisheries. While exact numbers are unknown, local residents and researchers estimate that there were only about 25 lagoon fishers in the 1960s (MARENA 2006). Fishers increased to about 200 in the 1990s and more than doubled in the 2000s (CIDEA 2006). In 2007, the municipality of Puerto Morazán had an estimated 300 lagoon shrimp fishers-200 of which resided in the community of Puerto Morazán—while Somotillo had another 200 (Gutierrez and Sanchez 2007). The 1990s shrimp boom also created a strong economic incentive for neighboring communities 
that were primarily agricultural, such as Palo Grande (Somotillo) and Rancheria (Chinandega), to start lagoon shrimp farming and shrimp fishing (Fig. 1). The entrance of new fishers created intercommunity conflicts over lagoon access. In the late 1990s, Palo Grande claimed the lagoon of Barillal and Rancheria claimed la Grentcha based on geographic proximity. This intercommunity conflict—which was sometimes violent—persisted despite inter-municipality negotiations (Gutierrez and Sanchez 2007). These violent interactions ranged from death threats, theft of fishing gear and boats, and fist fights (Gutierrez and Sanchez 2007, p. 16).

\subsection{Fishing Technological Changes}

Initial profits from shrimp farming allowed local fishermen to modernize their equipment, thus switching from paddle to motorized boats, and allowing households to build shrimp ponds in remote areas by increasing fishing range and efficiency. Fishing gear in the lagoons changed from cast nets to bag-nets with plastic water-retaining sheets called plastico (Fig. 4)—a very ecologically harmful technique (Gutierrez and Sanchez 2007).

Our logistic regression highlights the important role that a strong social network plays for mosos, but also indicates that households that engaged in shrimp farming earlier accumulated fishing assets. While it could be possible that the relationship is reversed, i.e., that wealthier fishermen primarily engaged in shrimp farming, interviews with local households tend to support the first assumption. Motor boats came in with shrimp cooperatives as illustrated by one interviewee: "I bought boat motors with the investment from the shrimp pond; the money from the shrimp pond helped a lot with trade as well."

Figure 4. Lagoon fishing technique (plastico), in Canta Gallo lagoon, wet season (2006)

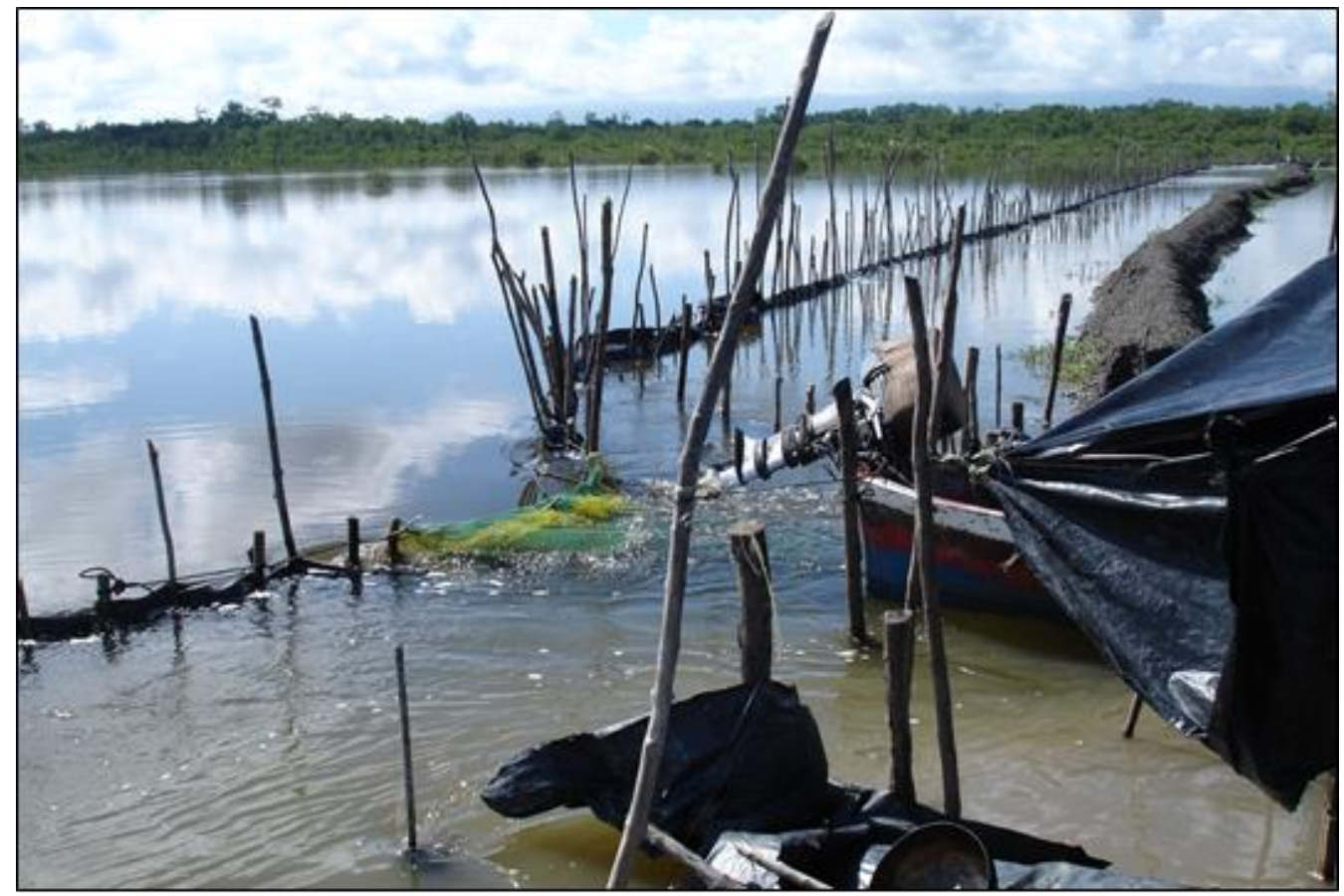


The development of plastico as a fishing technique mirrors that of aquaculture growth. In the mid-1980s, government officials brought a Mexican expert to show the tapos technique to a newly created fishermen's association in Puerto Morazán. The technique consisted of enclosing part of the seasonal lagoon with a barrier made of mangrove sticks and nets in order to capture shrimps more easily. An estimated 130 ha were enclosed (Curie 1994). The first year was a failure due to a ruptured wall but the second year was so successful that many of those that partook in the experiment reported investing in permanent assets such as houses: "With that [money] I bought my house" said one interviewee. However, the rest of the community objected to what was perceived as a privatization of the commons. Such statements show the strong resistance to the enclosure of the lagoons. "There was a fight to leave the lagoons alone" stated another interviewee. One fisherman involved in the tapos experiment recalls, "we wanted to continue in 1984 but since it was a natural lagoon, the community arose against it, they told us that we could not continue like that and so we left and we looked for a salt flat to build a shrimp pond". Establishing shrimp ponds on salt flats raised little community resistance given that these were considered barren areas of little interest beyond the occasional firewood and shellfish collection. On the contrary, lagoons with their high productivity were highly valued and their use was regulated.

The concept of the tapos remained however, and in the 1990s the use of plastico was introduced, becoming widely used in the early 2000s. Plastico consists of setting a mangrove stick barrier, similarly to the tapos technique, but instead of a net, durable black plastic is installed. In the middle of the structure, a passage is left for a bag-net that gathers shrimp and other aquatic species, increasing overall catch. This technology, as it evolved, was incompatible with common-pool resource management as it required significant investment in a permanent structure that could not be rotated, and thus was not shared among users. While not directly commented upon by the interviewees, there is a similarity between the technology employed in shrimp farms and that employed in lagoons. The use of plastico effectively creates mini ponds within the lagoons, becoming a sort of hybrid between human-made shrimp ponds and natural lagoon systems. Further, some interviewees mentioned that plastico started being used in reaction to observed biophysical change in the lagoon, namely the loss of water. Paradoxically, over the long term it created a negative feedback whereby sediment accumulated behind the wall instead of returning to the main channel of the estuary. This contributed to an overall decrease in lagoon depth with dramatic implications for lagoon fisheries.

Additionally, fishermen stated that in the long run, plastico prevented shrimp and other aquatic species' larvae from entering or exiting the lagoons, lowering the overall productivity and biodiversity of the system. Yet, despite an overwhelming condemnation of plastico, fishermen became locked in a prisoner's dilemma, whereby one fisherman's restraint is rewarded only if everyone else is also restrained. In absence of such guarantees, each individual fisherman adopted this technique not to be on the losing end. Characteristically, one fisherman said, "I am against the use of plastico but since the majority do it, I, in order to earn a bit, entered in this as well." Another stated, "people think: if I do not put plastico I am lost." Thus, the use of plastico created tension between those that can afford it and those who cannot. Indeed, plastico is expensive and needs to be 
replaced every 1-2 years, creating an economic barrier for many fishermen. A relatively poor fisherman mentioned that "those that have money have plastico, the others don't catch anything." Despite complaints about its negative environmental effects and its contribution to inequality of access, there is an economic incentive for the subgroup that possesses this equipment to extract resources intensively. "Those that have plastico do not want to remove it, they take advantage [of the lagoons] more than others" explained a shrimp fisher. The barrier to entry to the lagoons is also spatial given that the first plastico installed is in a better spot than the one behind it, and so forth. Acts of vandalism (plastico shredding and stealing, or destruction of the man-grove stick structure) were frequently reported, increasing the cost of maintaining a plastico structure, while decreasing levels of trust between fishermen.

\subsection{Shrimp Pond Growth}

There was a strong resistance to enclosing the lagoons in the early 1980s, even for temporary uses such as tapos. But gradually as shrimp aquaculture became entrenched, conversion of lagoons into shrimp ponds became accepted. Lagoon sites were particularly desirable due to their high productivity, especially for smaller scale shrimp farms that were heavily dependent on natural productivity and tide recycling for their operation (Tobey et al. 1998; Ochoa Moreno et al. 2001). Thus, most small-scale shrimp cooperatives are located near lagoons, while industrial shrimp ponds are more evenly distributed in the Estuary. In 2006, there were 3 industrial shrimp ponds and 13 small-scale cooperatives with about 10 members per cooperative occupying parts of Canta Gallo lagoon. Given that not all concessioned areas (i.e., areas with legal permits allowing aquaculture) are developed, an additional $45 \%$ of Canta Gallo could be converted to shrimp ponds, mostly by industrial actors.

Households were more concerned about the health and environmental issues associated with proximity to shrimp farms. Pollution from the effluents of shrimp ponds was identified as harmful for aquatic species, and industrial shrimp farms with their higher levels of inputs (e.g., antibiotics and feeds) were often blamed. Yet a long-term water quality assessment of the Estero Real found no conclusive evidence that shrimp farms were degrading the estuary (FAO 2012a, p. 4). Shrimp farms were also linked to the construction of ditches and canals in the lagoons. Many households blamed shrimp farms, especially industrial ones, for the creation of ditches which drained lagoon water into the estuary at a faster rate. This concern was also noted by Gutierrez and Sanchez (2007) in their diagnostic of conditions of the lagoons of the Estero Real. Lastly, tensions remain over what is perceived as an enclosure of the lagoons by shrimp ponds. Lagoon access close to small-scale shrimp farms was still possible by a virtue of being a community member. On the contrary, industrial shrimp farms often do not interact with local fishermen, and even place armed guards around their shrimp ponds to deter access (FAO 2012a).

\subsection{Climatic Drivers: The Interplay of Local and Global}

Adequate rainfall is essential to the existence of seasonal lagoons. Many interviewees mentioned that the local climate had 
changed and, in particular, that rainfall was less frequent and abundant. Hurricanes on the other hand, were reported as being more frequent and their timing less predictable. Informants said the local climate was hotter, affecting "both shrimp and people" as coined by one interviewee. Shrimp live in a specific temperature gradient and changes in water temperatures influence their productivity (Ochoa Moreno et al. 2001). Informants mentioned that a decrease in mangrove cover, and a change in mangrove species, in combination with climatic changes contributed to the increased water temperatures, which in turn affected shrimp productivity.

Additionally, in 1998, Hurricane Mitch had a profound impact on the lagoons. It flooded the estuary for about a week with $7 \mathrm{~m}$ of water (Núñez-Ferrera 2003). The main estuary channel became wider and shallower due to massive input of upper watershed sediments, a process facilitated by rapid deforestation upstream and degradation of sediment-retaining mangroves downstream. The lagoons of Canta Gallo had an additional $3 \mathrm{~m}$ of sediment deposited (CIDEA 2006). Water flows from Mitch also created new channels causing water to leave lagoons at a faster rate, often in areas where canals and ditches had already been created.

The reduction in water depth requires additional rain for seasonal lagoons to form. Yet, according to interviewees, the rainy season now starts later (in August-September occasionally October) and ends earlier (in November as opposed to MayDecember). Additionally, rainfall events are more unpredictable and more intense. These findings are consistent with the records of natural disasters patterns at regional and global scales for the area (Munich Re 2006; Magrin et al. 2007). For the people of Puerto Morazán, this means that the lagoon season is shorter with more frequent "extreme events" that affect both lagoon fisheries and aquaculture.

\section{5 The Cherry on the Pie: Organizational Conflicts}

A point came when the increased number of fishermen created conditions, whereby each individual fisherman had access to the lagoons only once or twice for the entire season, leading to very little overall gain from lagoon fisheries. This was compounded by the fact that some lagoons were taken over by other communities. Lastly, changes in technology created an incentive to free-ride for individual fishermen that had capital to invest to establish a permanent fishing spot within the lagoon rather than par-take in the common-property regime. Since these were among the richest and most powerful members of the community, the ability to monitor and restrict free-riders was compromised. The village committee was accused of either favoring their own family networks for the best shifts, or being so disorganized that appointments and enforcement were inefficient. When Hurricane Mitch radically transformed the lagoons' biophysical conditions, "nobody wanted to manage the system" clarified one interviewee.

\subsection{The Entrance of the State}

While at the community level, "nobody wanted to manage the system", the opposite occurred at the governmental level. 
While the area was protected on paper since the mid-1980s, a management plan for the Estero Real was finally concluded in 2006 as pressure mounted nationally to reconcile development and conservation goals in the region. The protected area expanded from 55,000 to 84,759.82 ha with an added buffer zone of 64,570.12 ha (MARENA 2006, p. 5). The protected area was divided in six major zones, including the aforementioned buffer zone. While seasonal lagoon fisheries are implicitly recognized in two of these zones, their management was not specifically discussed.

While many interviewees felt that protecting natural resources were positive, since it allowed fish and shrimp to reproduce and limited mangrove clearing, they also felt that restricting fishing and shrimp farming was unrealistic, since $70 \%$ of the community relies on extracting or farming aquatic resources. One interviewee stated, "When one has work, protecting is good but most people have no other alternative than to keep fishing." Consequently, many interviewees thought that the management plan did not correspond to local realities - especially that of fishermen — and was negative for local livelihoods. Additionally, in 2006, $20 \%$ of the households surveyed were not aware that a management plan was being prepared and potentially implemented in the estuary. More importantly people viewed MARENA, the environmental ministry, and by extension the management plan as promoting views at odds with local realities. These negative perceptions have implications for both the effectiveness and the legitimacy of the protected area. For instance, one interviewee mentioned that his cooperative decided to expand (beyond its allowed concession) to circumvent future protected area restrictions.

MARENA is aware of this issue and strives to involve local communities in a co-management effort (protected area meeting 2008) yet lack of funding, diverging national interests (i.e., between the legal mandate to protect the region and shrimp farming development goals), and limited human resources undermine implantation efforts. Currently establishing an effective management plan remains a challenge, and management has not been implemented yet (FAO 2012a). In 2009 and 2010, workshops were conducted to assess the feasibility of applying an ecosystem approach to fisheries and aquaculture in the Estero Real (FAO 2012a). Lagoon issues featured high in the prioritization of the problems associated with establishing an effective management system for the Estero Real. Bad management of the lagoons emerged as the first priority, along with the alteration of natural lagoons due to aquaculture and the use of harmful fishing techniques such as plastico in the lagoons.

\section{A Return to Common-Property Management?}

In 2008, the fishermen's committee of Puerto Morazán collaborated with a regional NGO in a UNEP project to restore Canta Gallo. The restoration project, conducted without a prior ecological assessment, built a wall around the lagoon of Canta Gallo in order to retain water in response to a decline in water level, an example of proto-aquaculture (Costa-Pierce 2008, p. $6)$.

Fishermen indicated that they were trying to return to common-property resource management, mostly because as noted by one interviewee "lagoons were drained." Small-scale shrimp farming was also in decline, as aquaculture consolidated in favor of the industrial sector, spurring many households to rely more heavily on fisheries (FAO 2012a). While the fishermen's 
"committee demonstrated how [a return to common-property resource management] would benefit the community" its leader said, "Some are not conforming even though it benefits the community." This new development happened after an inspection of fishing practices by the government which mandated fishermen to remove their plastico. Despite this positive development, the leader of the fishermen's committee mentioned the lack of monitoring as a major constraint. He said that "we need for the authorities to get involved [with monitoring] but they do not come to the lagoons. They do not know how people work. These fisheries technicians have salaries [to devote time to monitoring] but fishermen do not."

Gutierrez and Sanchez (2007) report that fishermen in Puerto Morazán organized themselves in 22 groups of 10 people each and efforts were made to restrict access to the estuary and the lagoons to 2 groups per day using 2 bag-nets each. Yet, based on a count of bag-nets, more than half did not belong to this new system. As of 2010, a fully functional commonproperty regime was not yet set in place in the lagoons (FAO 2012a).

\section{Discussion}

While the drivers of lagoon fisheries decline are multiple and cumulative, shrimp aquaculture fostered demographic, technological, environmental, and land tenure changes (see Fig. 5 for a graphical synthesis) in a pattern similar to that experienced by other tropical lagoons (Seixas and Troutt 2003; Kurien 2005; Berkes 2006; Nayak and Berkes 2010, 2011, 2012). In the Estero Real, the introduction of shrimp aquaculture initiated a process of decommonization, whereby the lagoons went from being managed as a common-property to being privatized in some parts, and becoming open-access in others; a complex mixed property regime. The privatization process is both direct, i.e., when ponds replace previous commons, and indirect, i.e., as new capital-intensive fishing technologies are adopted in the lagoon system (perhaps to mimic the technologies employed in shrimp farming). This process is not static and we may observe cycles of commonizations and decommonizations, as illustrated by more recent efforts to return to common-property management in Canta Gallo lagoons.

Technological change played a key role in decommonization. Shrimp aquaculture enabled the adoption of mechanized boats, and more costly and harmful fishing gear. Plastico restricted access to the lagoon not only due to its relatively high cost but also because its fixed structure prevents use by another fisher, thus spatially limiting access to the lagoons. This technological change, facilitated by shrimp aquaculture, also undermines the argument that shrimp aquaculture reduces pressure on wild fisheries. Instead, shrimp aquaculture indirectly enabled the adoption of harmful fishing techniques via the generation of necessary capital to increase shrimp fishing pressure.

The existence of social networks encompassing friends and extended family members allows poorer households to engage in lagoon fisheries, but this also highlights the risk that socially marginalized households are unable to access the lagoons. While not all households wanted to access the lagoons - a small subset of the community chose instead to specialize in seafood trading and service provision-most households that faced barriers to lagoon access consisted of the poorest households in the community. 
Figure 5. Aquaculture driven social-ecological changes in Esteral Real Lagoons, Nicaragua

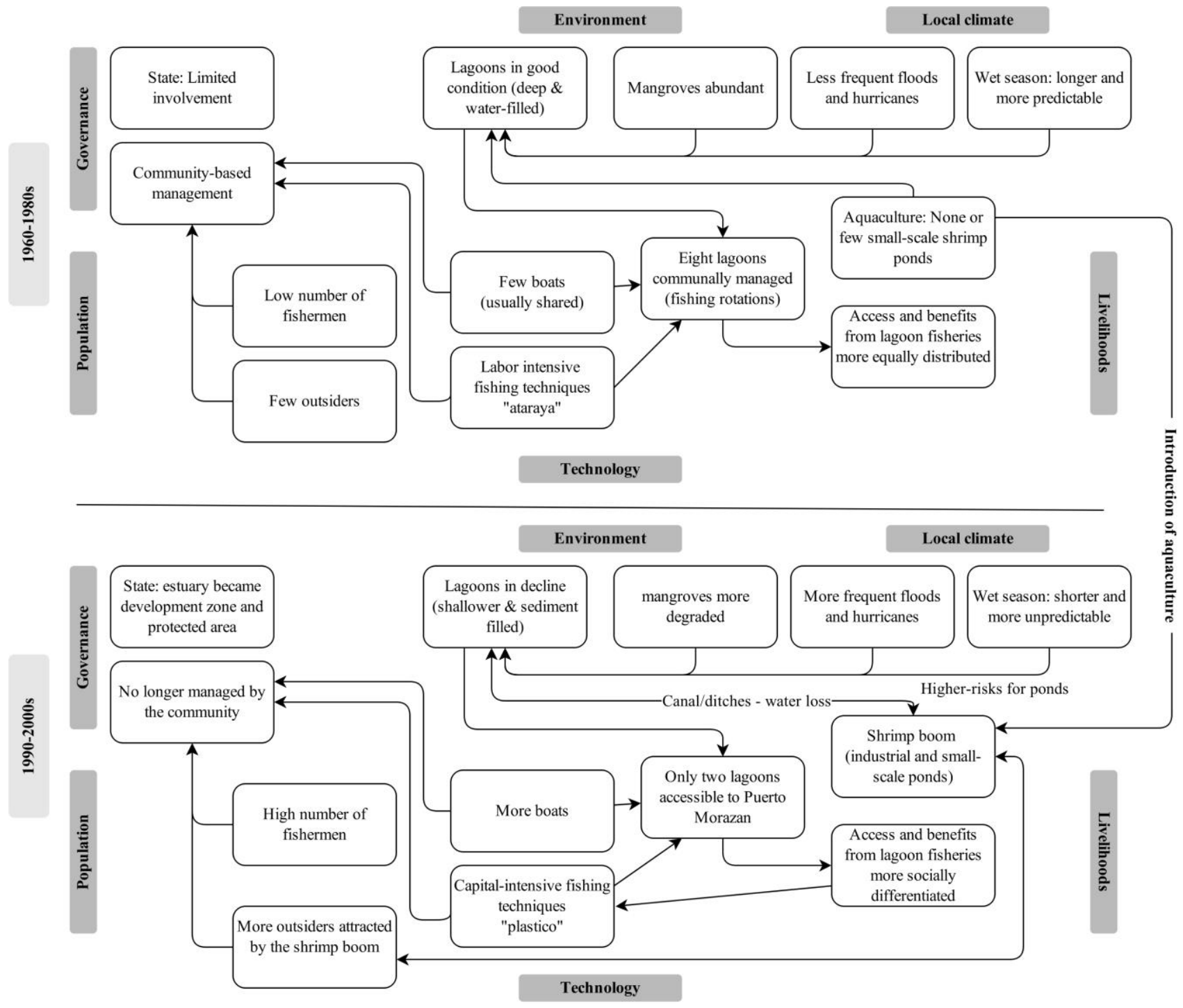

We observed a gradual privatization of the lagoon commons with muted conflict as opposed to the violent conflicts observed in neighboring Honduras (Stanley 1998; Stonich and Vandergeest 2001). One explanation is that change occurred from within the community as opposed to arising due to external threats. Islam (2008), Pradhan and Flaherty (2007) and Nayak and Berkes (2011) observe similar dynamics of social inequality rise and muted conflict in Bangladesh and India; often related to the entry of outsiders in the community. Indeed, local resistance to privatization of the lagoon commons was initially strong. But gradually as small-scale shrimp farmers became more numerous and benefits trickled down in the community, this resistance eroded. However, small-scale shrimp farmers find it exceedingly difficult to remain competitive in a changing economic and biophysical context. Costs of production are rising, shrimp prices decreased, and debts are accumulating. Additionally, natural disasters, small, and big, are recurring more frequently and are anticipated to become even more unpredictable with climate change. In 2006, shrimp farming consolidation was already under way, and continues today. This threat is by no means small given that in the 1980s, Nicaraguan cooperatives owned $100 \%$ of the industry, but their share dropped to $30 \%$ in the mid-1990s and $5 \%$ in 2005 (Coze Saborío 2006, p.5). For locals, lagoon fisheries emerge as a key 
alternative to declining revenues from small-scale shrimp farming.

As long as the privatization occurred among community members, social capital softened the experience of privatization, allowing hybrid uses of space. Access for instance to the lagoons was facilitated by the many social ties linking community members. As small-scale shrimp farmers lose their ponds, however, these former commons are lost to industrial actors with weaker ties to the community. This gradual privatization, and the subsequent consolidation of shrimp farms to the detriment of small-scale players, potentially lowers local community resistance because privatization due to shrimp farming is already an established concept. Indeed, shrimp ponds were initially converted to small-scale cooperatives. A similar process was observed in South East Asia where shrimp aquaculture first marginalized a segment of local communities, enhancing local elites, before marginalizing these same local elites that were not able to compete with larger external players (Lebel et al. 2002; Luttrell 2006).

In this new cycle toward commonization, illustrated by the efforts of local community members to restore commonproperty management, the state is called to play an important role. Indeed, current conditions differ from previous ones because the area is now connected to global markets and intrinsically part of competing national directives (development vs. conservation) at scale transcending the local level. Discussions have been initiated to establish a co-management structure with clear management guidelines oriented around ecosystem-based approaches to fisheries and aquaculture (FAO 2012a). Yet, interests differ between actors with unequal power relations and competing interests (i.e., small-scale vs. industrial shrimp farmers; lagoon fishers vs. government fisheries officials). To some extent, commonization is driven by threats to local sovereignty by the increased presence of the state, the deterioration of the natural resource base and the consolidation of the shrimp industry at the expense of small-scale actors.

The establishment of a co-management plan requires collectively negotiating land tenure rights and uses. This is challenged by the conflicts existing between communities and with the state, in a context of shrimp aquaculture consolidation which puts greater emphasis on the importance of lagoon fisheries. Realistic and compatible goals between environmental and development agendas need to be set. Greater policy weight needs to be given to resource uses other than for shrimp aquaculture. Finally, to become effective the protected area management needs to genuinely incorporate multiple actors in a multilevel governance system from sub-community groups to national levels (Berkes et al. 2003; Nayak and Berkes 2011, 2012), as opposed to creating new rules in a socially un-negotiated context. This highlights the fact that ecosystem-based approaches to aquaculture and fisheries do not pay enough attention to the social dynamics driving ecosystem change. 


\section{Conclusion}

The introduction of aquaculture radically transformed not only how the Estero Real lagoons were managed but also how they were perceived and valued. Aquaculture thus had impacts well beyond just the individual shrimp farm scale. Given a record of negative environmental and social impacts of aquaculture, we need an ecosystem approach to aquaculture and fisheries which integrates "the activity within the wider ecosystem in such a way that it promotes sustainable development, equity, and resilience of interlinked social and ecological systems" (Soto et al. 2008, p. 3). To do so, a nuanced understanding of social-ecological system dynamics is required.

Ecosystem-based approaches differ from social-ecological approaches in the attention given to social dynamics, and power in particular (Robards et al. 2011; Berkes 2012). We argue that ecosystem-based approaches need to adopt insights from social-ecological systems research to explicitly relate ecological processes to social dynamics such as changes in livelihood strategies, governance dynamics, knowledge systems, and power relations (Berkes et al. 2000, 2003; Peterson 2000; Folke 2006; Daw et al. 2011; Robards et al. 2011; Nayak and Berkes 2012).

In this study, we find that small-scale aquaculture played an important role in the gradual privatization of the lagoons (i.e., decommonization) by expanding onto lagoon areas - thus normalizing the conversion of lagoon commons-but also by enabling harmful fishing practices (i.e., plastico) that promoted individual uses of the lagoons. Yet, the existence of social ties between small-scale shrimp farmers and community members mitigated the experience of privatization, allowing benefits to trickle down and hybrid uses of lagoon space. However, as small-scale shrimp farmers lose ground to industrial actors and lagoon conditions deteriorate, efforts to commonly manage the lagoons (i.e., commonization) emerge once again, to safeguard access to an essential safety-net. The success of this transition will depend greatly on the ability of the community to constructively engage with other actors for the governance of the lagoons.

An ecosystem approach to aquaculture implies looking beyond just aquaculture. We focused here on the midscale, the community, but further works needs to link social-ecological dynamics at multiple scales. We also need to understand how to reconcile multiple interests and viewpoints into deliberative processes: only then can sustainable coastal management be negotiated in a way that considers aquaculture within the wider coastal social-ecological system.

Acknowledgments This research was supported by funding from the Levinson and Warren fellowships, the bourse MobilitéQuébec, McGill libraries and the International Development Research Center. We warmly thank the CIDEA institute for its field support, and in particular Juan Ramon Bravo, Eufresia Balladares, Will Herrera, Agnes Saborío Coze and Carlos Rivas for a fruitful exchange of ideas and for facilitating work in Nicaragua. We would also like to thank Oliver Coomes, Billie L. Turner II and Jesse Sayles for insightful comments on this manuscript. Oliver Coomes also provided valuable assistance during fieldwork and data analysis. Prateep Nayak provided valuable insights during the peer-review process. Two other anonymous reviewers contributed to the betterment of this paper. Last but not least, this work would not have been possible without the generous participation and support from the people of Puerto Morazán and other residents of the Estero Real. 


\section{References}

Adger WN (2000) Social and ecological resilience: are they related? Prog Hum Geogr 24:347-364. doi:10.1191/030913200701540465

Adger WN, Luttrell C (2000) Property rights and the utilisation of wetlands. Ecol Econ 35:75-89. doi:10.1016/S09218009(00) 00169-5

Agrawal A (2002) Common resources and institutional sustainability. In: Ostrom E et al. (eds) Committee on the Human Dimensions of Global Change. The drama of the commons. Washington, DC, pp 41-86

Allison EH, Ellis F (2001) The livelihoods approach and management of small-scale fisheries. Mar Policy 25:377-388. doi:10.1016/ S0308-597X(01)00023-9

Alongi DM (2002) Present state and future of the world's mangrove forests. Environ Conserv 29:331-349. doi:10.1017/S0376892902000231

Armitage D (2002) Socio-institutional dynamics and the political ecology of mangrove forest conservation in Central Sulawesi, Indonesia. Glob Environ Change 12:203-217. doi:10.1016/S0959-3780(02)00023-7

Benessaiah K (2008) Mangroves, shrimp aquaculture and coastal livelihoods in the Estero Real, Gulf of Fonseca, Nicaragua. Master of Science thesis, McGill University

Bergquist DA (2007) Sustainability and local people's participation in coastal aquaculture: regional differences and historical experiences in Sri Lanka and the Philippines. Environ Manage 40:787-802. doi:10.1007/s00267-006-0108-y

Berkes F (2006) From community-based resource management to complex systems: the scale issue and marine commons. Ecol Soc 11:45. http://www.ecologyandsociety.org/vol11/iss1/art45/

Berkes F (2012) Implementing ecosystem-based management: evolution or revolution? Fish Fish 13:465-476. doi:10.1111/j.1467-2979.2011.00452.x

Berkes F, Seixas CS (2005) Building resilience in lagoon social-ecological systems: a local-level perspective. Ecosystems 8:967-974. doi:10. 1007/s10021-005-0140-4

Berkes F, Folke C, Colding J (2000) Linking social and ecological systems: management practices and social mechanisms for building resilience. Cambridge University Press, Cambridge

Berkes F, Colding J, Folke C (2003) Navigating social-ecological systems: building resilience for complexity and change. Cambridge University Press, New York

CIDEA (2006) Línea de base y referencia de governance: Puerto Morazán. Centro de Investigación de Ecosistemas Acuáticos, Universidad Centroamericana (CIDEA-UCA), Managua

Costa-Pierce BA (2008) Ecological aquaculture: the evolution of the blue revolution, 2nd edn. Wiley-Blackwell, Oxford

Cox DR, Snell EJ (1989) The analysis of binary data, 2nd edn. CRC Press, Boca Raton

Coze Saborío A (2006) Visión general del sector acuícola de Nicaragua y análisis prospectivo del desarrollo futuro. Centro 
de Investigación de Ecosistemas Acuáticos, Universidad Centroamericana (CIDEA-UCA), Managua

Crona B, Bodin O (2006) What you know is who you know? Communication patterns among resource users as a prerequisite for co-management. Ecol Soc 11:7. http://www.ecologyandsoci ety.org/vol11/iss2/art7/

Curie DJ (1994) Ordenamiento de la camaronicultura: Estero Real, Nicaragua. Fortalecimiento de la Acuicultura, Programa Regional de Apoyo al desarrollo de la Pesca en el Istmo Centroamericano (PRADEPESCA), Unión Europea-OLDEPESCA

Daw T, Brown K, Rosendo S, Pomeroy R (2011) Applying the ecosystem services concept to poverty alleviation: the need to disaggregate human well-being. Environ Conserv 38:370-379. doi:10.1017/S0376892911000506

Dewalt BR, Vergne P, Hardin M (1996) Shrimp aquaculture development and the environment: people, mangroves and fisheries on the Gulf of Fonseca, Honduras. World Dev 24:1193-1208. doi:10.1016/0305-750X(96)00033-2

Donato DC, Kauffman JB, Murdiyarso D, Kurnianto S, Stidham M, Kanninen M (2011) Mangroves among the most carbon-rich forests in the tropics. Nat Geosci 4:293-297. doi:10.1038/ngeo1123

Donnelly C (2007) Shrimp aquaculture in Nicaragua. Ecology of Aquaculture Studies and Reviews. University of Rhode Island, Kingston

Ellis F (1998) Household strategies and rural livelihood diversification. J Dev Stud 35:1-38. doi:10.1080/00220389808422553

FAO (2006) Ecosystem approach to aquaculture (EEA). FAO Fisheries and Aquaculture Department, Rome FAO (2007) The world's mangroves: 1980-2005. FAO Forestry Paper 153. Food and Agricultural Organization of the United Nations, Rome

FAO (2009) The state of the world fisheries and aquaculture: 2008. FAO Fisheries and Aquaculture Department, Food and Agriculture Organization of the United Nations, Rome

FAO (2012a) Informe de los talleres sobre la introducción al enfoque ecosistémico a la pesca y la acuicultura. FAO Informe de Pesca y Acuicultura 994/1, Rome

FAO (2012b) The state of the world fisheries and aquaculture: 2012. FAO Fisheries and Aquaculture Department, Food and Agriculture Organization of the United Nations, Rome

Folke C (2006) Resilience: the emergence of a perspective for social- ecological systems analyses. Glob Environ Change 16:253-267. doi:10.1016/j.gloenvcha.2006.04.002

Frankic A, Hershner C (2003) Sustainable aquaculture: developing the promise of aquaculture. Aquacult Int 11:517-530. doi:10. 1023/B:AQUI.0000013264.38692.91

Gowing JW, Tuong TP, Hoanh CT, Khiem NT (2006) Social and environmental impact of rapid change in the coastal zone of Vietnam: an assessment of sustainability issues. In: Hoanh CT et al (eds) Environment and livelihoods in tropical coastal zones: managing agriculture-fishery_aquaculture conflicts. CABI Press, Oxfordshire, pp 48-60

Gutierrez R, Sanchez R (2007) Diagnostico de la actividad pesquera artesanal en el Estero Real. Centro de Investigaciones 
Pesqueras y Acuícolas (CIPA), Instituto Nicaragüense de la Pesca y Acuicultura (INPESCA), Managua

Hardin G (1968) Tragedy of commons. Science 162:1243-1248. doi:10.1126/science.162.3859.1243

Hay I (2005) Qualitative research methods in human geography. Oxford University Press, Oxford

Horton L (2007) Grassroots struggles for sustainability in Central America. University Press of Colorado, Boulder

Hosmer D, Lemeshow S (2000) Applied logistic regression. Wiley, New York

Huong TTT, Berkes F (2011) Diversity of resource use and property rights in Tam Giang Lagoon, Vietnam. Int J Commons 5:130-149

Islam MS (2008) In search of "white gold”: environmental and agrarian changes in rural Bangladesh. Soc Nat Res 22:6678. doi:10.1080/08941920801942255

Kalikoski DC, Vasconcellos M, Lavkulich L (2002) Fitting institutions to ecosystems: the case of artisanal fisheries management in the estuary of Patos lagoon. Mar Policy 26:179-196. doi:10. 1016/S0308-597X(01)00048-3

Kapetsky JM (1981) Some considerations for the management of coastal lagoon and estuarine fisheries. FAO Fisheries Technical Paper 218, p 47

Kent G (1997) Fisheries, food security, and the poor. Food Policy 22:393-404

King MW (2010) Analyzing environmental conflicts: actor network approaches and the analysis of discourse: a case study in southern Honduras. UpSidEo Publishing

Kurien J (2005) Evolving towards unsustainability: a personal statement on Kerala's marine fishery spanning three decades. Int J Rural Manage 1:73-96. doi:10.1177/097306800400100105

Lacerda LD (2002) Mangrove ecosystems: function and management. Springer, Berlin

Lebel L, Tri NH, Saengnoree A, Pasong S, Buatama U, Thoa LK (2002) Industrial transformation and shrimp aquaculture in Thailand and Vietnam: pathways to ecological, social and economic sustainability. Ambio 31:311-323. doi:10.1579/0044-7447-31.4.311

Lugo AE (2002) Conserving Latin American and Caribbean mangroves: issues and challenges. Madera y Bosques, numero especial pp 5-25

Luttrell C (2006) Adapting aquaculture in Vietnam: securing livelihoods in a context of change in two coastal communities. In: Hoanh CT et al (eds) Environment and livelihoods in tropical coastal zones: Managing agriculturefishery—aquaculture conflicts. CABI Press, Oxfordshire, pp 17-29

Magrin G, Gay C, Cruz D, Gimenez JC, Moreno AR, Nagy GJ, Nobre C, Villamizar A (2007) Latin America, climate change 2007: impacts, adaptation and vulnerability. Contribution of Working Group II to the 4th Assessment Report of the IPCC, pp 581-615 MARENA (2006) Plan de manejo: Reserva natural del delta del Estero Real. MARENAMIFIC-CPC, Managua

Martinez-Alier J (2001) Ecological conflicts and valuation: mangroves versus shrimps in the late 1990s. Environ Plan C 19:713-728. doi:10.1068/c15s 
Menard S (2000) Coefficients of determination for multiple logistic regression analysis. Am Stat 54:17-24. doi:10.1080/00031305. 2000.10474502

MIFIC (2007) Boletín de comercio exterior de Nicaragua (2006). Dirección de Política Comercial Ministerio de Fomento, Industria y Comercio MIFIC-DGCE, Managua

MIFIC (2013) Informe anual de comercio exterior e IED (2012). Dirección de Política Comercial Ministerio de Fomento. Industria y Comercio MIFIC-DGCE, Managua

Moberg F, Ronnback P (2003) Ecosystem services of the tropical seascape: interactions, substitutions and restoration. Ocean Coast Manage 46:27-46. doi:10.1016/s0964-5691(02)00119-9

Moreno Ochoa et al (2001) Methods for improving shrimp farming in Central America. UCA Press, Managua

Munich Re (2006) Hurricanes: more intense, more frequent, more expensive. Munich Reinsurance Company and American Reinsurance Company

Nagelkerke NJ (1991) A note on a general definition of the coefficient of determination. Biometrika 78:691-692

Nagelkerken I, Blaber SJM, Bouillon S, Green P, Haywood M, Kirton LG, Meynecke JO, Pawlik J, Penrose HM, Sasekumar A (2008) The habitat function of mangroves for terrestrial and marine fauna: a review. Aquat Bot 89:155185. doi:10.1016/j.aquabot. 2007.12.007

Nayak PK, Berkes F (2010) Whose marginalisation? Politics around environmental injustices in India's Chilika lagoon.

Local Environ 15:553-567. doi:10.1080/13549839.2010.487527

Nayak PK, Berkes F (2011) Commonisation and decommonisation: understanding the processes of change in the Chilika lagoon, India. Conserv Soc 9:132-145. doi:10.4103/0972-4923.83723

Nayak PK, Berkes F (2012) Linking global drivers with local and regional change: a social-ecological system approach in Chilika lagoon, Bay of Bengal. Reg Environ Change 1-12. doi:10.1007/ s10113-012-0369-3

Núñez-Ferrera M (2003) Propuesta de ordenamiento del concesionamiento de tierras salitrosas para establecimiento de granjas camaroneras en el pacifico nicaragüense. Ministerio de Fomento, Industria y Comercio, Dirección General de Recursos Naturales (PASMA-MIFIC), Managua

Ostrom E (1990) Governing the commons: the evolution of institutions for collective action. Cambridge University Press, New York

Ostrom E, Burger J, Field CB, Norgaard RB, Policansky D (1999) Sustainability—revisiting the commons: local lessons, global challenges. Science 284:278-282. doi:10.1126/science.284. 5412.278

Paez-Osuna F (2001a) The environmental impact of shrimp aquaculture: a global perspective. Environ Pollut 112:229231. doi:10. 1016/S0269-7491(00)00111-1

Paez-Osuna F (2001b) The environmental impact of shrimp aquaculture: causes, effects, and mitigating alternatives. Environ Man-age 28:131-140. doi:10.1007/s002670010212

Peng CYJ, Lee KL, Ingersoll GM (2002) An introduction to logistic regression analysis and reporting. J Educ Res 96:3-14 
Peterson G (2000) Political ecology and ecological resilience: an integration of human and ecological dynamics. Ecol Econ 35:323-336. doi:10.1016/S0921-8009(00)00217-2

Polidoro BA, Carpenter KE, Collins L, Duke NC, Ellison AM, Ellison JC, Farnsworth EJ, Fernando ES, Kathiresan K, Koedam KE (2010) The loss of species: mangrove extinction risk and geographic areas of global concern. PLoS One 5:e10095. doi:10.1371/journal.pone.0010095

Pradhan D, Flaherty M (2007) National initiatives, local effects: trade liberalization, shrimp aquaculture, and coastal communities in Orissa, India. Soc Nat Resour 21:63-76. doi:10.1080/ 08941920701655734

Primavera JH (1997) Socio-economic impacts of shrimp culture. Aquac Res 28:815-827. doi:10.1046/j.13652109.1997.00946.x

Ramsar (2000) Ficha informativa: Deltas del Estero Real y llanos de Apacunca. Universidad Centroamericana (UCA), PROGOLFO-Nicaragua, CATIE/OLAFO/DANIDA, Proyecto Corredor Biologico Mesoamericano (CBM), MARENA

Robards MD, Schoon ML, Meek CL, Engle NL (2011) The importance of social drivers in the resilient provision of ecosystem services. Glob Environ Change 21:522-529. doi:10. 1016/j.gloenvcha.2010.12.004

Scoones I (1998) Sustainable rural livelihoods: a framework for analysis. IDS Working Paper 72

Seixas CS (2000) State-property, communal-property or open-access? The case of Ibiraquera lagoon, Brazil. In: IACSP conference proceedings, Bloomington

Seixas CS, Berkes F (2003) Dynamics of social-ecological changes in a lagoon fishery in southern Brazil. In: Berkes F et al (eds) Navigating social-ecological systems: building resilience for complexity and change. Cambridge University Press, New York

Seixas CS, Troutt E (2003) Evolution of a local Brazilian shrimp market.Ecol Econ 46:399-417. doi:10.1016/S09218009(03)00082-X

Singh A (2005) One planet, many people: atlas of our changing environment. United Nations Environment Programme Slocombe DS (1993) Implementing ecosystem-based management.Bioscience 43:612-622. doi:10.2307/1312148

Soto D, Aguilar-Manjarrez J, Hishamunda N (2008). Building an ecosystem approach to aquaculture. In: Soto et al. (eds) Expert Workshop. Fisheries and aquaculture proceedings, FAO, Rome, 7-11 May 2007

Stanley DL (1996) David vs. Goliath: fishermen conflicts with mariculturalists in Honduras. In: Collin H (ed) Green guerillas: environmental conflicts and initiatives in Latin America and the Caribbean: a reader. Monthly Review Press, New York

Stanley DL (1998) Explaining persistent conflict among resource users: the case of Honduran mariculture. Soc Nat Res 11:267-278. doi:10.1080/08941929809381079

Stevenson JR, Irz X, John-Smith O (2009) Is aquaculture development an effective tool for poverty alleviation? A review of theory and evidence. Cahiers d'Agriculture 18:292-299. doi:10. 1684/agr.2009.0286 
Stonich SC (1989) The dynamics of social processes and environ-mental destruction: a Central American case study. Popul Dev Rev 15:269-296

Stonich SC (1995) The environmental-quality and social-justice implications of shrimp mariculture development in Honduras. Hum Ecol 23:143-168. doi:10.1007/BF01191647

Stonich SC, Bailey C (2000) Resisting the blue revolution: contend-ing coalitions surrounding industrial shrimp farming. Hum Organ 59:23-36

Stonich SC, Vandergeest P (2001) Violence, environment, and industrial shrimp farming. In: Peluso N, Watts M (eds) Violent environments. pp 261-286

Stonich SC, Bort JR, Ovares LL (1997) Globalization of shrimp mariculture: the impact on social justice and environmental quality in Central America. Soc Nat Res 10:161-179. doi:10. 1080/08941929709381016

Tidwell JH, Allan GL (2001) Fish as food: aquaculture's contribution: ecological and economic impacts and contributions of fish farming and capture fisheries. EMBO Rep 2:958-963. doi:10. 1093/embo-reports/kve236

Tobey J, Clay J, Vergne P (1998) Maintaining a balance: the economic, environmental, and social impacts of shrimp farming in Latin America. Coastal Resources Center, University of Rhode Island, Kingston

Turner BL, Kasperson RE, Matson PA, McCarthy JJ, Corell RW, Christensen L, Eckley N, Kasperson JX, Luers A, Martello ML, Polsky C, Pulsipher A, Schiller AM (2003) A framework for vulnerability analysis in sustainability science. PNAS 100:8074- 8079

Turner S (2007) Small-scale enterprise livelihoods and social capital in eastern Indonesia: ethnic embeddedness and exclusion. Prof Geogr 59:407-420. doi:10.1111/j.1467-9272.2007.00631.x

Valiela I, Bowen JL, York JK (2001) Mangrove forests: one of the world's threatened major tropical environments. Bioscience 51:807-815

Vásquez DP, Méndez M, Martínez R (2005) Informe de evaluación y ordenación de recursos pesqueros en el golfo de Fonseca, Honduras. Cooperación Española (AECI) y DIGEPESCA

Walters BB, Ronnback P, Kovacs JM, Crona B, Hussain SA, Badola R, Primavera JH, Barbier E, Dahdouh-Guebas F (2008) Ethnobiology, socio-economics and management of mangrove forests: a review. Aquat Bot 89(2):220-236. doi:10.1016/j. aquabot.2008.02.009

Wittenstein P (2007) Aquaculture as a means to improve social and economic conditions in Nicaragua. Ecology of Aquaculture Studies and Reviews. University of Rhode Island, Kingston 